\title{
Kolokacje w tekstach prawnych - wykonanie orzeczenia
}

\author{
Collocations in legal texts - \\ enforcement of a judgment 'wykonanie orzeczenia'
}

\author{
Andrzej Moroz \\ Wydział Filologiczny, Uniwersytet Mikołaja Kopernika w Toruniu, \\ ul. Fosa Staromiejska 3, 87-100 Toruń, Polska; \\ e-mail: amoroz@umk.pl
}

\begin{abstract}
Abstrakt
Prezentowany tekst stanowi egzemplifikację zautomatyzowanych procedur identyfikacyjnych omówionych w zamieszczonym w niniejszym tomie artykule Kolokacje w tekstach prawnych - problemy proceduralne. Zasadniczym jego celem jest scharakteryzowanie jakościowych procedur analizy kolokacji, stanowiących kolejny etap statystycznego opracowania takiego zbioru wyrażeń. Podstawą obserwacji będą właściwości dwustronnej kolokacji wykonanie orzeczenia.
\end{abstract}

Słowa kluczowe: język specjalistyczny; tekst prawny; kolokacja; analiza jakościowa kolokacji.

\begin{abstract}
Presented text is an exemplification of automated identification procedures of collocations discussed in the article included in this volume Collocations in legal texts - procedural issues. Its main aim is to characterize qualitative procedures for collocations analysis, representing the next stage of statistical analysis of such expressions. The basis of observation will be features of bilateral collocation enforcement of a judgment - 'wykonanie orzeczenia'.
\end{abstract}

Keywords: language for special purposes; legal text; collocation; qualitative analysis of collocations.

\section{Wstęp}

Jak wiadomo, opis języka jest przede wszystkim charakterystyką systemu. To na nim koncentrują swoje obserwacje badacze. Podejście takie jest bez wątpienia słuszne i prowadzi w prostej linii do odpowiedzi na pytanie o status i funkcję określonych modeli porozumiewania. Wydaje się jednak, że w dążeniu do odkrywania mechanizmów systemowych warto niekiedy pochylić się nad tekstem, choćby z tego względu, aby dowiedzieć się więcej o sposobie aktualizacji abs- 
trakcyjnej potencji języka w określonych typach komunikatów. Odpowiedź na tak sformułowane pytanie jest szczególnie cenna w odniesieniu do charakterystyki różnych odmian specjalistycznych współczesnej polszczyzny. $Z$ tego też powodu przedmiotem prowadzonych tu rozważań będą teksty pochodzące $\mathrm{z}$ kodeksów polskiego prawa karnego, podczas gdy zasadniczym celem jest próba wskazania konstytutywnych cech występującej w nich kolokacji dwustronnej - wykonanie orzeczenia. Tekst niniejszy jest egzemplifikacją tez badawczych opisanych w artykule zamieszczonym w niniejszym tomie: Kolokacje w tekstach prawnych problemy proceduralne. Tam to zostały zdefiniowane wykorzystywane tu zarówno terminy, jak i procedury analityczne.

1.1. W opisach tekstów specjalistycznych, szczególnie prawnych, pokutuje opinia, że różnią się one od tzw. języka ogólnego przede wszystkim strukturą leksyki, co dobitnie pokazują prace z zakresu prawa. Uznaje się bowiem, że

język prawny jest częścią języka naturalnego, a tym samym, tym co odróżnia te języki, są jedynie różnice występujące w sferze słownictwa i semantyki. Jeżeli chodzi natomiast o składnię tych języków, to [...] uznać należy, że składnia stosowana w tekstach aktów normatywnych jest taka sama jak składnia stosowana w tekstach języka powszechnego (Petzel 2011: 160).

Rozwiązania takie prowadzą do ograniczania pola analiz do warstwy leksykalnej. Jak się jednak wydaje, nie muszą one być trafne, a dogłębna analiza tekstów prawnych pozwala na sformułowanie wniosku, że również poziom gramatyczny szczególnie składniowy - winien być uwzględniany przy opisie różnic między tekstami prawnymi a tekstami języka ogólnego. Hipotezę taką uznaje się w niniejszym artykule za podstawową przesłankę prowadzonego wnioskowania. Jej potwierdzeniem są występujące w tekstach prawnych konstrukcje składniowe, których struktura jest zdeterminowana pod względem leksykalnym i formalnym. Tym samym analiza ograniczeń wewnętrznych i zewnętrznych tworzenia takich ciągów stanowi ważny etap definiowania normy składniowej rządzącej tekstami z zakresu prawa.

1.2. Druga przesłanka wynika z przeświadczenia o konieczności zdefiniowania kierunków rozbieżności zachodzących pomiędzy tekstami języka ogólnego a tekstami prawnymi, co jest motywowane dwoma tezami szczegółowymi. Pierwsza z nich została sformułowana przez Andrzeja Bogusławskiego, który uznał, że w opisie języka istotne są najdrobniejsze różnice zachodzące zarówno w płaszczyźnie treści, jak i formy (por. Bogusławski 1988, 2005, Bogusławski, Danielewiczowa 2005). Druga z kolei nawiązuje do pojęcia tzw. nieswobodnej grupy syntaktycznej. W tym opracowaniu pojęcie to odnosi się do połączenia elementów leksykalnych, które jest budowane z ograniczeniami, objawiającymi się zakłóceniami złożeniowości w płaszczyźnie semantyki lub syntaktyki (por. Йорданская, Мельчук 2007, Gębka-Wolak, Moroz 2014). Uznaje się tym samym, że cechą tekstów prawnych jest tworzenie połączeń zgodnie z jasno określonym systemem ograniczeń. Istnieje mianowicie w nich grupa ciągów, w których wybór poszczególnych podciągów jest realizowany zgodnie z pewnymi ogólnymi wymogami. 
Wychodząc z takiego założenia, dąży się tu do wskazania ograniczeń łączliwości jednostek leksykalnych, co potwierdza tezę o odmiennym charakterze kolokacji w tekstach prawnych i świadczy o specyfice tego kodu.

\section{Wykonanie orzeczenia - cechy kolokacji}

Przykładem wyrażenia tworzonego w sposób ograniczony jest połączenie $w y$ konanie orzeczenia. Zgodnie z przyjętymi wcześniej założeniami jest to kolokacja dwustronna. Pierwszy jej człon konstytuuje bowiem w analizowanych kodeksach $\mathrm{w}$ jednej z możliwych form (wykonania, wykonanie, wykonaniu, wykonaniem) łącznie 1604 kolokacje, z czego w jego prawostronnym kontekście forma jednostki orzeczenie wystąpiła 265 razy (16,52\%). Formy leksemu ORZECZENIE (orzeczenia, orzeczenie, orzeczeń, orzeczeniu, orzeczeniem, orzeczeniach, orzeczeniami) z kolei łączyły się z komponentem wykonanie 265 razy na 1880 wszystkich możliwych kolokacji (co stanowi 14,09\%).

\subsection{Ograniczenia formalne}

Analizowana tu kolokacja ma kształt grupy nominalnej, której pierwszy komponent nakłada - zgodnie ze składnią rządu - ograniczenia formalne na sposób realizacji składnika drugiego (Gen), jak również otwiera dla niego pozycję wymaganą. $\mathrm{Z}$ tego też powodu zarówno postać gramatyczna składnika orzeczenia, jak i jego obecność podlegają determinacji, której złamanie jest sygnałem niekolokacyjności połączenia, por.

(1) Sad, kierujac do wykonania orzeczenie o pozbawieniu wolności, zawiadamia... ${ }_{\text {KKW } 17,1}$

W przeciwieństwie do ograniczeń, którym podlega składnik orzeczenia, postać gramatyczna prepozycyjnego komponentu - wykonanie - jest zależna od wymagań kontekstu zewnętrznego i nie obserwuje się w tym zakresie wyraźnych obostrzeń, por.

(2) ...prokurator przed podjęciem decyzji w przedmiocie wykonania orzeczenia informuje... ${ }_{\mathrm{KPK}} 606 \mathrm{zh}, 5$

(3) ... prawa moga zostać naruszone przez wykonanie orzeczenia. ${ }_{\mathrm{KPK}} 611 \mathrm{fx}, 1$

(4) Koszty zwiazane z wykonaniem orzeczenia [...] ponosi Skarb Państwa. ${ }_{\text {KPK } 611 \text { uj }}$

W sposób niejednolity z kolei są realizowane ograniczenia linearyzacyjne struktury wykonanie orzeczenia. $\mathrm{Z}$ jednej strony bowiem wyrażenie to charakteryzuje się stabilizacją szyku wewnętrznego - w całym korpusie nie istnieje potwierdzenie szyku odwrotnego - z drugiej zaś ciąg ten nie wykazuje ograniczeń - poza standardowymi - linearyzacji zewnętrznej. Może on wystąpić zarówno w interpozycji, jak i antepozycji czy postpozycji ciągu zdaniowego, por. 
(5) Skazany ma obowiazek stosować się do wydanych przez właściwe organy poleceń zmierzających do wykonania orzeczenia.

(6) Można odmówić wykonania orzeczenia o zatrzymaniu dowodów... $\mathrm{KPK}_{589 \mathrm{~m}, 1}$

(7) Wykonanie tego orzeczenia $w$ tym trybie ustaje $w$ dniu przekazania... ${ }_{\mathrm{KKW}} 245$

Do istotnych cech dystynktywnych należy natomiast fakt zajmowania przez analizowaną kolokację zależnej pozycji w wyrażeniu zdaniowym. W takiej sytuacji bezpośrednim nadrzędnikiem dystrybucyjnym ciągu wykonanie orzeczenia bywa czasownik, por. (11), rzeczownik (często gerundialny), por. (8) i (12), przymiotnik, por. (9), i przyimek, por. (10):

(8) Kto, w celu udaremnienia wykonania orzeczenia sadu lub innego organu państwowego, udaremnia lub uszczupla zaspokojenie swojego wierzyciela... ${ }_{\mathrm{KK}} 300,2$

(9) Sad, który wydat orzeczenie w pierwszej instancji, jest właściwy również w postępowaniu dotyczacym wykonania tego orzeczenia.

(10) Skazany ma obowiazek stosować się do wydanych przez właściwe organy poleceń zmierzających do wykonania orzeczenia.

(11) W razie wniesienia kasacji Sąd Najwyższy może wstrzymać wykonanie zaskarżonego orzeczenia $\ldots$ KPK 532,1

(12) Przed uptywem terminu [...] sąd albo prokurator informuje właściwy organ sądowy państwa wykonania orzeczenia o zamiarze zwolnienia spod zatrzymania... KРК 589s, 3

Brak jest również wyraźnych ograniczeń związanych z typem konstrukcji, w której może pojawić się analizowane tu wyrażenie. Ciąg taki występuje bowiem zarówno jako składnik zdań prostych, por. (11) czy (12), jak i podrzędnych (w tym względnych) - (13). Może on dodatkowo stanowić współskładnik konstrukcji współrzędnej, por. (14):

(13) Można odmówić wykonania orzeczenia [...], jeżeli: [...] 10) zachodzi uzasadniona obawa, że wykonanie orzeczenia może naruszyć prawa osób trzecich.

(14) Minister Sprawiedliwości określi [...] wzór zawiadomienia [...], zawierajac $w$ nim informacje dotyczqce $[. .$.$] organów państwa wydania i wykonania$ orzeczenia... ${ }_{\mathrm{KPK}} 611 \mathrm{tb}, 5$

Jest rzeczą znamienną, że struktura kolokacyjna wykonanie orzeczenia może być również rozwijana przez podrzędniki dystrybucyjne. W tym wypadku są one jednak zasadniczo zależne od postpozycyjnego składnika kolokacji, poprzedzając go w linearnym układzie wyrażenia - por. podrzędniki liczebnikowe lub przymiotnikowe w (15) i (16) - względnie następując po nim, por. wyrażenie przyimkowe w (16). Zdecydowanie rzadziej (w analizowanym zbiorze istnieje tylko jeden typ takiej struktury) przyjmuje dodatkowy podrzędnik składnik wykonanie, por. (17):

(15) Jeżeli mienie podlegające egzekucji nie jest wystarczające do wykonania dwóch lub więcej orzeczeń... ${ }_{\mathrm{KPK}} 611 \mathrm{fz}$ 
(16) Zatrzymanie dowodów [...] trwa do czasu rozstrzygnięcia [...], odpowiednio o wydanie dowodów albo o wykonanie wniosku o wykonanie prawomocnego orzeczenia o przepadku. ${ }_{\mathrm{KPK}} 589 \mathrm{~s}, 1$

(17) [...] Ponowne wystapienie do innego państwa wykonania orzeczenia może nastapić jedynie $w$ razie niewykonania albo częściowego wykonania orzeczenia.

KPK $607 \mathrm{zd}, 3$

\subsection{Ograniczenia leksykalne}

2.2.1. Analiza kolokacji winna obejmować również zespół ograniczeń leksykalnych nakładanych na ich człony. Procedura ich określania uwzględnia m.in. wariantywny sposób realizacji podciągów takiej struktury. W wypadku połączenia wykonanie orzeczenia $\mathrm{w}$ prawostronnym kontekście wyrażenia wykonanie w pozycji składnika orzeczenia może wystąpić rzeczownik kary (139 wystąpień), nakazu (28), postanowienia (19), czynności (13). Rzadziej pojawi się tu przyimek - wykonania $w-22$, wykonania na - 10 czy wykonania za - 8. Realizacje przyimkowe stanowią jednak $\mathrm{w}$ gruncie rzeczy adiunktywne rozwinięcie gerundium wykonanie (zajmują inną pozycję składniową), podczas gdy konieczny element dopełniaczowy występuje bądź w kontekście niebezpośrednim, bądź ma realizację zerową:

(18) Są [...] nadaje na żadanie osoby uprawnionej klauzulę wykonalności orzeczeniu podlegającemu wykonaniu $w$ drodze egzekucji. ${ }_{\text {КРК 107,1 }}$

Jak można przypuszczać, inne połączenia mają bądź charakter przypadkowy *wykonania zastępczej, bądź niską frekwencję tekstową - wykonanie wniosku - 4. Z kolei w kontekście lewostronnym leksemu WYKONANIE pojawiają się zazwyczaj jednostki przyimkowe, tworzące wraz z gerundium konstrukcje składniowe (do wykonania, o wykonanie, $z$ wykonaniem). Z innych połączeń tego typu należy wspomnieć o strukturach państwo wykonania, przedmiot wykonania czy zawieszenie wykonania. We wszystkich tych zestawieniach wykonanie jest elementem zależnym od składnika kontekstu lewostronnego, nie nakłada ponadto na niego żadnych ograniczeń leksykalnych.

Wymienność w swoim lewostronnym kontekście dopuszcza również postpozycyjne wyrażenie analizowanej kolokacji, a mianowicie ORZECZENIE. W tym wypadku możliwe - choć frekwencyjnie rzadsze - jest połączenie wydania orzeczenia - 128 wystąpień, a już marginalny charakter mają struktury: odpis orzeczenia -17 , dotyczy orzeczenia - 11 czy otrzymania orzeczenia - 10 . Inne ciągi lewostronnego kontekstu mają bądź charakter przypadkowy (np. *ie orzeczenie), bądź też realizują inny typ struktury - jak choćby ciągi z przyimkiem występującym w prepozycji analizowanego rzeczownika (np. od orzeczenia). W kontekście prawostronnym z kolei najwyższą frekwencją charakteryzują się przyimki, por. orzeczenie o - 149 wystąpień - oraz rzeczowniki: sq̨du - 19 oraz przepadku - 13, por. 
(19) Postanowienie w przedmiocie wykonania orzeczenia o zatrzymaniu dowodów $[\ldots]$ sąd albo prokurator wydaje niezwłocznie.... К К $5899_{n}, 1$

(20) Można odmówić wykonania orzeczenia przepadku korzyści majątkowej albo jej równowartości [...], w części, w której orzeczenie przepadku byłoby niedopuszczalne wedtug prawa polskiego. ${ }_{\mathrm{KPK}} 611 \mathrm{fw}, 2$

Pozostałe połączenia formy orzeczenia - choć częste - mają w gruncie rzeczy charakter przypadkowej styczności, podczas gdy realizowane wyrażenia przyimkowe łączą się strukturalnie z innym składnikiem danego przepisu prawnego, por. orzeczenie $w$ - 56 czy orzeczenie do - 44:

(21) [...] sq̨d wzywa wlaściwy sąd lub inny organ państwa wykonania orzeczenia do przekazania całości albo części wyegzekwowanej kwoty lub mienia innego niz pieniqqdze, uzyskanych z tytułu wykonania orzeczenia, zgodnie z po-

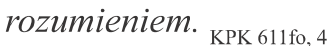

Rozważanie powyższego problemu wprowadza nas w zagadnienie tzw. wariantów kolokacji. Teza taka wymaga jednak głębszego przemyślenia i szerszego uzasadnienia, na co nie ma tu miejsca.

2.2.2. Z ograniczeniami leksykalnymi wiąże się też problem znaczeń komponentów wyrażenia wykonanie orzeczenia. Słowniki języka polskiego definiują pierwszy człon tej kolokacji przez odesłanie do czasownika. Nieprzystające są bowiem definicje, które pojmują wykonanie jako 'sposób zrobienia czegoś' lub 'publiczną prezentację utworu, zwłaszcza muzycznego' (ISJP). Stosowne definicje czasownika wykonać wskazują natomiast na 'zrobienie czegoś, urzeczywistnienie, zrealizowanie' (SJPSz), na 'rozpoczęcie jakiejś czynności i jej zakończenie' (ISJP), względnie na 'zrobienie czegoś' (WSJP). Słowniki nie nakładają jednak wyraźnych ograniczeń na sposób realizacji prawostronnego kontekstu zarówno czasownika wykonać, jak i gerundium wykonanie. Najczęściej w tej pozycji występuje 'nazwa czynności lub jej rezultat' - skoki, odwierty, praca, polecenie, plan, zamiar, doświadczenie, ruch.

Jak można przypuszczać, kontekst prawostronny występowania w karnym module prawnym gerundium wykonanie winien spełniać wymagania analogiczne do notowanych przez słowniki języka ogólnego ('czynność bądź jej rezultat'). Wydaje się w tym wypadku, że rezultatywny charakter członu postpozycyjnego jest tu jednak dominujący, por. orzeczenie - 'to, co się orzekło' czy wniosek - 'to, co się wnioskuje'. Jeżeli zgodzimy się z tym faktem, trzeba również zaakceptować tezę o braku specjalnych ograniczeń łączliwości na poziomie semantycznym. Inaczej jest w stosunku do poziomu leksykalnego. Bo jak możliwe są połączenia wykonanie polecenia czy pracy, tak już wystąpienie wyrażeń wykonanie ruchu czy obrotu (WSJP) lub wykonanie skoku czy odwiertu (ISJP) w kodeksach prawnych

${ }^{1}$ Interpretacja znaczeń predykatów jest zgodna z koncepcją Romana Laskowskiego (1998: 156) oraz Renaty Grzegorczykowej (2001: 107). Wydaje się, że w takim wypadku należałoby zaliczyć wyrażenia kontekstu prawostronnego do działań, kontrolowanych akcji podmiotu zmierzających do zmian w obiekcie. 
jest mało prawdopodobne. Wskazane ograniczenie ma - jak się wydaje - przede wszystkim jednak podłoże pragmatyczne. Nienaturalność połączeń ?wykonanie skoku czy ? wykonanie ruchu w module karnym wynika bowiem z faktu, że trudno jest zdefiniować sytuacje, w których ich użycie byłoby uzasadnione².

W wypadku komponentu orzeczenie słowniki wskazują na istotne składniki definicji. Mówi się, że 'orzeczenie to coś, co zostało oficjalnie orzeczone w danej sprawie, np. opinia, postanowienie lub wyrok' (ISJP) bądź wprost 'rozstrzygnięcie konkretnej sprawy przez sąd $\mathrm{i}$ inne organy rozstrzygające, wydane w postaci wyroku lub postanowienia' (SJPSz) oraz 'oficjalne rozstrzygnięcie w określonej sprawie' (WSJP). W analizowanych kodeksach samo wyrażenie łączy się lewostronnie z dwoma typami kontekstów. Pierwszy ma charakter czynnościowy (wydanie orzeczenia, otrzymanie orzeczenia) - drugi zaś określający (prawomocne orzeczenie, zaskarżone orzeczenie). Konteksty te de facto nie wykluczają się, por. o wykonanie prawomocnego orzeczenia. Analizowana w tym tekście kolokacja wykorzystuje pierwszy typ kontekstu - czynnościowy, choć nie istnieją wyraźne ograniczenia nakładane na sposób jego realizacji, por. wydanie, otrzymanie, przekazanie, przejęcie, podanie, uchylenie, uzasadnienie, utrzymanie, kwestionować, zaskarżyć, sprostować itp.

\subsection{Komentarz normatywny}

Orzekanie o poprawności dowolnego wyrażenia jest realizowane na podstawie jego porównania $\mathrm{z}$ ciągiem uznawanym za wzorcowy. Wzorzec taki jest wskazany albo przez słowniki normatywne, albo przez uzus, którego wykładnikiem może być korpus danego języka. Należy jednak przyjąć, że dowolny słownik poprawnościowy nie może notować wszystkich akceptowalnych form wyrazowych, a tym samym przyjmuje się, że brak orzeczenia oznacza akceptację danej formy bądź struktury. W wypadku analizowanego w tym miejscu ciągu Stownik poprawnej polszczyzny nie wypowiada się ani w kwestii łączliwości normatywnej, ani nienormatywnej zarówno wyrażenia wykonanie, jak i orzeczenie. Brak jest też takich orzeczeń w hasłach czasowników motywujących oba składniki kolokacji.

Nieco inne dane otrzymamy jednak podczas analizy kolokacji języka ogólnego podawanych głównie przez Kolokator Pelcry oraz Hask - najnowszą wyszukiwarkę pracującą również na danych generowanych przez Pelcrę ${ }^{3}$. Dodajmy, że bezpośrednie porównywanie wyników może być w tym wypadku mylące z uwagi na różnice w sposobie wyznaczania systemu hierarchii. Istotne jest jednak to, że

${ }^{2}$ Rozumienie pragmatyki jako działu językoznawstwa określającego ,system reguł przyporządkowujących wyrażenia językowe klasom sytuacji, których uczestnikami są użytkownicy języka" pochodzi od Adama Bednarka i Macieja Grochowskiego (1993: 10). Z kolei różne podejścia do rozumienia takich badań zostały opisane przez Iwonę Kaproń-Charzyńską (2014: 18-19).

${ }^{3}$ Kolokator jest dostępny na stronie: http://www.nkjp.uni.lodz.pl/collocations.jsp, a Hask http://pelcra.clarin-pl.eu/hask_pl (zob. Pęzik 2013). 
otrzymujemy informację o liczbie wystąpień ośrodka kolokacji, liczbie zlematyzowanych kolokacji konstytuowanych przez ten ośrodek oraz liczbie kolokatów. Kolokator więc, pracując na zrównoważonej próbce Narodowego Korpusu Języka Polskiego o wielkości 10000 segmentów, wskazał 537 typów kolokacji dla 8357 wystąpień wyrażenia wykonanie. Jest rzeczą znamienną, że najwyższą frekwencją charakteryzują się kolokaty przymiotnikowe - nienależyte wykonanie, zdalne wykonanie czy brawurowe wykonanie - oraz czasownikowe - zlecać wykonanie, umożliwiać wykonanie. W kontekście prawostronnym najczęściej występują rzeczowniki: wykonanie budżetu, wykonanie kary, wykonanie zadania oraz zdecydowanie rzadziej - przyimki: wykonanie na czy wykonanie przez. Podobne informacje przekazuje program Hask, który dla 9449 wystąpień form wyrażenia wykonanie wskazał 317 połączeń z kolokatem przymiotnikowym - artystyczne wykonanie, dobre wykonanie, swoje wykonanie, $133 \mathrm{z}$ kolokatem czasownikowym - podlegaja wykonaniu, ustyszeć wykonanie oraz $110 \mathrm{z}$ kolokatem rzeczownikowym - (w) wykonaniu zespolu, (w) wykonaniu teatru, wykonanie zadania, wykonanie budżetu.

Korpus języka ogólnego pokazuje tym samym, że w kontekście prawostronnym wyrażenia wykonanie mogą wystąpić zarówno argumenty propozycjonalne (nieprzedmiotowe), np. wykonanie polecenia, wykonanie zlecenia, por.

(22) Mimo wykonania zobowiqzania musieliby oni liczyć się z możliwościa obowiąku dalszego świadczenia. NKJP

(23) Bombowiec podchodzit do strategicznych instalacji wojskowych NATO i portów na odległość wystarczająca do wykonania uderzenia. NKJP' jak i przedmiotowe (wykonanie kopii, wykonanie instrukcji, wykonanie testu), (zob. Karolak 2002), por.

(24) Wykonanie drogi byłoby zbyt kosztownym przedsięwzięciem. NKJP

Analiza danych prowadzi z kolei do istotnych wniosków ogólnych. Otóż możliwe jest przeprowadzenie granicy pomiędzy połączeniami typowymi a marginalnymi. Za połączenia typowe moglibyśmy uznać struktury z przymiotnikami, np. artystyczny, nienależyty, zdalny, lub czasownikami, np. podlegać, zlecać. $\mathrm{W}$ interesującym nas kontekście prawostronnym z kolei systemowo pojawiłyby się takie rzeczowniki, jak dokumentacja, budżet, umowa, podczas gdy interesujące nas orzeczenie stanowiłoby łączliwość marginalną. W Kolokatorze Pelcry wystąpiło ono bowiem 18 razy, co więcej w większości są to potwierdzenia z kodeksów prawnych. Taki stan rzeczy prowadzi do wniosku, że teksty prawne mogą być uznane za przykład subnormy języka specjalistycznego. Wyzyskując bowiem ogólne modele języka, ograniczają one zestaw wykorzystywanych środków językowych.

Na marginesie warto dodać, że najczęstszy w języku ogólnym typ łączliwości - z prepozycyjnym kolokatem przymiotnikowym - w tekstach prawnych niemal nie występuje. W analizowanych kodeksach bowiem pojawiły się zaledwie 4 typy takich struktur (czesściowe wykonanie, prawidłowe wykonanie, natychmiastowe 
wykonanie, nieumiejętne wykonanie) o sumarycznej liczbie 21 realizacji na 1448 ustalonych klastrów kolokacyjnych.

Zbliżone wnioski nasuwają się podczas analizy listy kolokatów rzeczownika orzeczenie, ustalonej dla języka ogólnego. Dominujące są tu struktury rzeczownikowe (orzeczenie trybunału, orzeczenie sadu, orzeczenie przepadku) i przymiotnikowe (prawomocne orzeczenie, orzeczenie lekarskie). Kolokator notuje również analizowane tu połączenie wykonanie orzeczenia, jednak o niezbyt wysokiej frekwencji (61 wystąpień), por.

(25) Mieli na to tydzień od publikacji prawomocnego orzeczenia. ${ }_{\text {NKJP }}$

(26) Gdy jest wyrok, następuje wykonanie orzeczenia ... NKJP

Jak można wobec tego sądzić, w wypadku analizowanej tu kolokacji - wykonanie orzeczenia - mamy do czynienia $\mathrm{z}$ dwustronnym ograniczeniem leksykalnym sposobu realizacji argumentów nieprzedmiotowych.

\subsection{Problem ciągów kolokacyjnych}

Na koniec warto podnieść pewien problem metodologiczny związany z opisem kolokacji występujących w tekstach prawnych. Otóż przyjęte zautomatyzowane kryteria wyróżniania kolokacji pozwalają na wskazanie ciągów dwuelementowych, w których co najmniej jeden składnik nakłada ograniczenia leksykalno-gramatyczne na sposób realizacji składnika drugiego ${ }^{4}$. Zdarza się jednak, że jeden i ten sam element jest komponentem więcej niż jednej kolokacji, co prowadzi do tworzenia tzw. ciągów kolokacyjnych. Są to ponaddwuelementowe struktury leksykalne, w których poszczególne składniki są powiązane zależnościami kolokacyjnymi - nakładają na komponenty sąsiadujące ograniczenia leksykalno-gramatyczne, względnie takie ograniczenia przyjmują. W wypadku analizowanej w tym miejscu kolokacji może być ona częścią co najmniej pięciu różnych ciągów kolokacyjnych (udaremnienie wykonania orzeczenia sqadu; wstrzymanie wykonania orzeczenia; zabezpieczenie wykonania orzeczenia o; przedmiot wykonania orzeczenia; państwo wykonania orzeczenia), por.

(27) Kto, w celu udaremnienia wykonania orzeczenia sqdu lub innego organu państwowego, udaremnia lub uszczupla zaspokojenie swojego wierzyciela [...] podlega karze pozbawienia wolności od 3 miesięcy do lat $5 .{ }_{\mathrm{KK}} 300,2$

(28) Wstrzymanie wykonania orzeczenia można połaczyć z zastosowaniem środków określonych $w$ art. 266, 271, 272, 275 i 277. ${ }_{\text {KPK 532,2 }}$

(29) $W$ razie popetnienia przestępstwa, z urzędu może nastapić zabezpieczenie wykonania orzeczenia o kosztach sadowych w postępowaniu karnym na mieniu oskarżonego. ${ }_{\text {KPK } 291,3}$

${ }^{4}$ Informacja o sposobach ustalania kształtu kolokacji i wyróżniania ich typów została omówiona w znajdującym się w niniejszym tomie artykule Kolokacje w tekstach prawnych - problemy proceduralne. 
(30) Do czasu rozpoczęcia wykonania kary w państwie wykonania orzeczenia sad może odstapić od wystapienia... ${ }_{\mathrm{KPK}} 611 \mathrm{tc}, 2$

Naturalnie opis tego typy struktur jest zdecydowanie bardziej złożony niż charakterystyka prezentowanej w tym tekście kolokacji dwuelementowej, niemniej wydaje się on konieczny przy założeniu, że prowadzone obserwacje mają mieć charakter kompletny.

\section{Wnioski}

Przeprowadzona w niniejszym tekście analiza przykładowej kolokacji dwustronnej, wyekscerpowanej z tekstów prawnych, zdaje się potwierdzać skuteczność wypracowanych narzędzi identyfikacji oraz opisu ustabilizowanych połączeń składniowych. Jak się wydaje, teksty prawne obfitują w struktury, które od swoich odpowiedników z języka ogólnego różnią się siłą restrykcji wewnętrznych. Nie zmienia to faktu, że rozważania powyższe stanowią jedynie początek długofalowych badań tekstów prawnych. Wydaje się jednak, że ich podjęcie jest konieczne. Jest bowiem rzeczą pożądaną ustalenie zestawu struktur kluczowych dla prawnego subkodu komunikacyjnego, gdyż są one istotnym elementem interpretacji prawa. Część z nich bez wątpienia stanowi bądź to terminy tego języka, bądź też ustabilizowane jednostki leksykalne. Ich wyłapanie oraz precyzyjne scharakteryzowanie wydaje się najważniejszym zadaniem na przyszłość.

\section{Rozwiązanie skrótów wykorzystywanych kodeksów}

KK - Kodeks karny, Ustawa z dnia 6 czerwca 1997 r. (z późniejszymi zmianami) KKW - Kodeks karny wykonawczy, Ustawa z dnia 6 czerwca 1997 r. (z późniejszymi zmianami)

KPK - Kodeks postępowania karnego, Ustawa z dnia 6 czerwca 1997 r. (z późniejszymi zmianami)

KPW - Kodeks posteppowania w sprawach o wykroczenia, Ustawa z dnia 24 sierpnia 2001 r. (z późniejszymi zmianami)

KW - Kodeks wykroczeń, Ustawa z dnia 20 maja 1971 r. (z późniejszymi zmianami)

\section{Bibliografia}

Bednarek A., Grochowski M., 1993, Zadania z semantyki językoznawczej, Toruń.

Bogusławski A., 1988, Język w stowniku, Wrocław.

Bogusławski A., 2005, Przypomnienia metodologiczne, „Biuletyn Polskiego Towarzystwa Językoznawczego" 61, s. 189-196. 
Bogusławski A., Danielewiczowa M., 2005, Verba Polona Abscondita. Sonda słownikowa III, Warszawa.

Gębka-Wolak M., Moroz A., 2014, O nieswobodnej grupie syntaktycznej, „Prace Językoznawcze" t. 16, z. 1, s. 45-61.

Grzegorczykowa R., 2001, Wprowadzenie do semantyki językoznawczej, Warszawa.

Йорданская Л.Н., Мельчук И.А., 2007, Смысл и сочетаемость в словаре, Москва.

Kaproń-Charzyńska I., 2014, Pragmatyczne aspekty słowotwórstwa. Funkcja ekspresywna i poetycka, Toruń.

Karolak S., 2002, Podstawowe struktury składniowe języka polskiego, Warszawa.

Laskowski R., 1998, Fleksja, w: Gramatyka współczesnego języka polskiego. Morfologia, t. 1, red. R. Grzegorczykowa, R. Laskowski, H. Wróbel, Warszawa, s. 125-150.

Petzel J., 2011, Status lingwistyczny języka prawnego, w: Prawo, język, media, red. A. Mróz, A. Niewiadomski, M. Pawelec, Warszawa, s. 153-165.

Pęzik P., 2013, Paradygmat dystrybucyjny w badaniach frazeologicznych. Powtarzalność, reprodukcja i idiomatyzacja, w: Metodologie językoznawstwa. 1. Ewolucja języka. Ewolucja teorii językoznawczych, red. P. Stalmaszczyk, Łódź, s. 143-160. 